\title{
Willingness to Adopt Certifications and Sustainable Production Methods among Small-Scale Cocoa Farmers in the Ashanti Region of Ghana
}

\author{
Robert Aidoo ${ }^{1} \&$ Ingrid Fromm ${ }^{2}$ \\ ${ }^{1}$ Department of Agricultural Economics, Agribusiness and Extension, Kwame Nkrumah University of Science \\ and Technology, Ghana \\ ${ }^{2}$ School of Agricultural, Forest and Food Sciences, Bern University of Applied Sciences, Switzerland \\ Correspondence: Robert Aidoo, Department of Agricultural Economics, Agribusiness and Extension, Kwame \\ Nkrumah University of Science and Technology, Ghana. E-mail: badubob@yahoo.co.uk
}

\author{
Received: October 17, 2014 Accepted: November 4, 2014 Online Published: January 22, 2015 \\ doi:10.5539/jsd.v8n1p33 URL: http://dx.doi.org/10.5539/jsd.v8n1p33
}

\begin{abstract}
The main objective of this research project was to identify current cocoa production practices and determine the principal factors that affect the adoption of sustainable farming practices and socio-environmental certifications among small-scale cocoa farmers in Ghana. The study was conducted in two cocoa districts (Atwima Mponua and Ahafoano North) in the Ashanti Region of Ghana. A combination of stratified, systematic and random sampling techniques was employed to select 439 cocoa producing households for the study. A standardized structured questionnaire was used to gather field data through personal interviews. Results showed that membership in farmers' organizations, awareness of certification and size of cocoa farm were the main determinants of willingness to adopt sustainable cocoa production methods and certifications. Whereas membership in farmer-based organizations and awareness about different aspects related to certification had a significant positive effect on adoption of cocoa certification, farm size tended to have a significant negative effect on adoption of certification. Formation of cocoa farmers' associations/organizations in various communities, creation of awareness about certification and continuous education of cocoa farmers are recommended to stimulate adoption of cocoa certification to achieve sustainability in the Ghanaian cocoa industry.
\end{abstract}

Keywords: certification, cocoa, sustainability, Ghana

\section{Introduction}

Cocoa has historically been a key economic sector and a major source of export earnings in Ghana (Bulir, 1998; McKay \& Arytee, 2005). Cocoa bean exports account for about 40 percent of the country's foreign exchange earnings and provide the second largest source of export dollars. However, according to the Bank of Ghana, export receipts of cocoa beans and products for the first quarter of 2011 amounted to $\$ 859.4$ million accounting for about 61 percent of total export earnings as compared with $\$ 682.5$ million for 2010 which was 48.8 percent (GAIN, 2012; ISSER, 2011).The share of cocoa in Ghana's GDP rose from $2.5 \%$ in 2009 to $3.6 \%$ in 2011(GSS, 2012. Cocoa's share of agricultural GDP rose from 13.7\% in 2004 to $18.9 \%$ in 2006 (Breisingeret al., 2008). Cocoa's share of agricultural GDP has been increasing rapidly, and prospects of continued high world commodity prices suggest further growth potential. Cocoa contributes about 70 per cent of annual income of small-scale farmers, and stakeholders like Licensed cocoa Buying Companies (LBC's) also depend largely on cocoa beans for their trading and marketing activities, employment, and income generation (Asamoah \& Baah, 2003).

In Ghana, growth in the cocoa sector has been achieved by increasing the area cultivated rather than by improving yield (MOFA 2006; Cocoa Board, 2007). Cocoa yields in Ghana are well below international averages, suggesting potential for productivity driven growth (ICCO, 2007). Achievable yields for cocoa are around 1-1.5 tons per hectare, more than double the average yields recorded in Ghana in 2005 (MOFA, 2007). While the average cocoa yield in Malaysia is $1800 \mathrm{~kg}$ per hectare, and that for Cote d'Ivoire is $800 \mathrm{~kg}$ per hectare, yield is only $360 \mathrm{~kg}(0.36 \mathrm{mt})$ per hectare in Ghana (Abekoeet al., 2002). Yields have been fairly stable 
since 2005, ranging from 0.38 to 0.42 metric tonnes /ha between 2005 and 2010 (FAO, 2013). Ghana's cocoa yield has been on average 25 percent less than the average yield level of the ten largest cocoa producing nations and nearly 40 percent below the average yield level of neighboring Côte d'Ivoire (Mohammed et al, 2011). Reasons for the low productivity in Ghana include adoption of traditional production methods, poor farm maintenance practices, planting low-yielding varieties, and the incidence of pests and diseases (Abekoe et al., 2002). Binam et.al (2008) also reported that Ghana appears to be the least efficient in cocoa production compared to other cocoa producing countries in West Africa like Nigeria, Cote d'Ivoire and Cameroon. Cocoa productivity levels can be enhanced either by improving technical efficiency and/or by improving technological application or sustainable production methods (Nkamleu et al, 2010). One of the major objectives of stakeholders in the Ghanaian cocoa industry is to increase production on a sustainable basis at the farm level. Proper farm maintenance through weeding and increased use of inputs like pesticides and fertilizers are considered to be the most effective way to increase cocoa production. This is because a greater part of cocoa produce is lost through diseases, pests and weeds on the farm (Binam et al, 2008). For these reasons, efficiency and sustainable production methods continue to be very important subjects of empirical investigation particularly in developing economies where majority of farmers are resource-poor (Amos, 2007; Binam et al, 2008; Nkamleu et al, 2010).

Small-scale farmers are often poorly linked to markets and benefit the least from the cocoa value chain and Ghana clearly illustrates this point (Chamberlain, 2008; Dormon et al., 2004). Empirical evidence suggests that private certification initiatives, such as organic and fair trade labels guarantee that farmers and producers are paid better prices (Doherty \& Tranchell, 2005; Doherty \& Meehan, 2006). Efforts in other sectors to increase yields with innovative and sustainable farming practices have helped build equitable input-output markets and allowed farmers to increase their profits.

Sustainable production of cocoa is essential to sustainable development in Ghana. There is a trend towards less shaded cocoa landscapes that undermines the environmental sustainability of cocoa production and biodiversity conservation. Given continued use of zero-input production techniques and the dependence on fertile soils offered by old forests, both low-shade cocoa cultivation and slash and burn approaches to land clearance have led to soil degradation. Thus, unsustainable production and harvesting practices slowly deplete forest soils of major nutrients, soil carbon, and organic matter. The expansion in production landscape for cocoa in Ghana over the last three decades has led to significant forest loss through promotion of zero shade cocoa production systems (UNDP, 2012). This has gradually led to the fragmentation of forest landscapes, loss of wildlife corridors and forest connectivity, and degradation of biodiversity as well as goods and services offered by these ecosystems. One of the more prominent consequences of deforestation, which has significantly affected cocoa production, is a significant loss of major soil nutrients. This has been a leading cause of the gradual decline of national cocoa yields. Land tenure issues have also facilitated forest loss by removal of forests to establish cocoa farms. This has constrained expansion of more environmentally sound production (i.e. greater shade). Today farmers have very limited incentive to plant or maintain shade trees because of tenure issues with landowners, and landowners have limited rights to naturally occurring trees on their land.

Unsustainable production methods have driven cocoa farmers to extend into forested areas but they are now left with little land for further expansion. In fact, many cocoa farms in Ghana today need to be rehabilitated if productivity declines are to be reversed. Overcoming some of the major environmental threats to sustainable cocoa production such as deforestation and habitat conversion; unsustainable intensified production system; unsustainable land management practices and resource use; and climate change will require a considerable shift in cocoa farming and related practices. Cocoa cultivation that maintains higher proportions of shade trees (cocoa agroforestry) is increasingly being viewed as a sustainable land use practice that is environmentally preferable to other forms of agricultural activities in tropical forest regions because it contributes to biodiversity conservation. There should be a focus on establishing and maintaining forest tree species to favor species richness, alternative income options, habitat creation, crop microclimates, soil fertility, and reduced plant stress (UNDP, 2012). This will need to be accompanied by other environmentally sound production practices that assist in the rejuvenation of ecosystem goods and services and on-farm biodiversity. However, many of the sustainable practices like the best practices for composting and soil management, water catchment to maintain soil humidity, and pesticide usage are not fully understood by farmers. This knowledge gap has to be addressed by research and training. Also, land tenure issues need to be resolved to promote forest tree plantings. The lack of market-based approaches to incentivize farmers to adopt environmental best practices will need a thorough investigation (UNDP, 2012). Additionally, improving relationships between buyers and sellers, reducing transaction costs and improving economies of scale by market information systems is important (Toenniessen et al., 2008). In fair 
trade production systems, where working together with chocolate companies and traders is a common practice, cocoa farmers in Ghana have been motivated by the relationship with buyers, the availability of information and aid in the compliance with fair trade labels (Doherty \&Tranchell, 2005). Farmers not only receive a better price for their cocoa, but support is also provided to improve their agricultural practices and comply with standards, therefore improving their livelihoods.

\section{Method}

The study was conducted in two cocoa districts (Atwima Mponua and Ahafoano North) in the Ashanti Region of Ghana. A combination of stratified, systematic and random sampling techniques was employed to select 439 cocoa producing households for the study. A standardized structured questionnaire was used to gather field data through personal interviews.

Descriptive statistics such as arithmetic mean and standard deviation as well as frequency distribution tables were used to summarize respondents' characteristics. A binary logistic regression model was used to examine the factors that determine farmers' willingness to adopt certification.

Mathematically, logit probability is represented by:

Where:

$$
\phi\left(z_{i}\right)=e \frac{z_{i}}{1+e^{z_{i}}}=\frac{1}{1+e^{z_{i}}}-\infty<\mathrm{Z}_{\mathrm{i}}<\infty
$$

$Z_{i}=\beta X_{i} ; \beta$ a vector of unknown coefficients; $X_{i}$ a vector of factors/characteristics of the $i^{\text {th }}$ farmer; $\Phi\left(\beta X_{i}\right)$ is the probability that the $i^{\text {th }}$ factor will affect farmer's willingness to adopt cocoa certification.

The probability that a given factor affects farmer's decision to adopt certification is the area under the standard normal distribution curve between $-\infty$ and $\beta X_{i}$. The larger the value of $\beta X_{i}$, the more important the factor is in affecting farmer's decision-making. The change in $\Phi\left(\beta X_{\mathrm{i}}\right)$ relative to the change in $\mathrm{X}_{\mathrm{i}}$ is given by:

$$
\frac{\delta \phi\left(\beta x_{i}\right)}{\delta x_{i j}}=\left[\frac{\delta \phi}{\delta z_{i}}\right]\left[\frac{\delta z_{i}}{\delta x_{i j}}\right]=f\left(z_{i}\right) \beta_{j}
$$

Where $f\left(Z_{i}\right)$ is the value of density function associated with each value of the underlying $Z_{i}$ index.

Farmers' decision to adopt certification is influenced by a vector of factors, $X_{i}$, including farmers' characteristics, socio-economic factors and institutional/technical factors.

The empirical logit model was specified as:

$$
\log \left[P_{i} /\left(1-P_{i}\right)\right]=\beta_{0}+\sum_{i j=1}^{n k} \beta X_{i j}+\varepsilon_{i}
$$

Where:

$\mathrm{P}_{\mathrm{i}}=$ Probability that a farmer is willing to adopt certification

$\beta_{0}=$ Constant

$\sum_{i j=1}^{n k} \beta X_{i j}=$ vector of all the explanatory variables

$\beta_{\mathrm{i}}=$ Parameters/coefficients of the explanatory variables, and

$\varepsilon_{\mathrm{i}}=$ Random/disturbance term.

The following variables were included in the model:

$\mathrm{X}_{1}=$ Sex of farmer $($ Male $=1 ;$ Female $=0)$

$\mathrm{X}_{2}=$ Years of formal education

$\mathrm{X}_{3}=$ Farm size (acres)

$\mathrm{X}_{4}=$ Farming experience (years)

$\mathrm{X}_{5}=$ Extension visits last year

$\mathrm{X}_{6}=$ Membership of Farmer Based Organization ( $1=$ Yes; $0=$ No)

$\mathrm{X}_{7}=$ Access to Credit $(Y e s=1 ; N o=0)$ 
$\mathrm{X}_{8}=$ Awareness of certification $(Y e s=1 ; \mathrm{No}=0)$

The maximum likelihood estimation procedure was used to obtain the model estimates.

\section{Results}

A total of 439 cocoa producers were surveyed for this study (Table 1). Over 60 percent of the farmers were conventional farmers. There are fewer certified farmers in the Ashanti region, and most of them have been certified for about two years. They came from two cocoa districts in the Ashanti region of Ghana. Seventy-five per cent of the interviewed farmers were male and at least half were FBO members of farmer-based organizations (FBO).However, only 20 per cent of the interviewed farmers were members of cocoa farmer associations. In Ghana, Farmer-based organizations (FBOs) are the same as farmer associations. However, in this context, FBOs represent all farmer organizations (without any focus on any particular crop, so farmers who belong to cassava farmers associations are also members, as are yam and cowpea farmers associations, for example. The Cocoa Farmers' Association, on the other hand, is for only cocoa farmers.

Despite the high rate of membership to associations, about 90 per cent of the farmers had no access to credit. This is not surprising because, most of the FBOs in Ghana are formed for special projects and marketing purposes with credit not being the main focus. In the specific case of cocoa farmers, groups are formed for certification purposes and also to facilitate subsidized input distribution by government through such farmer organizations. Although over half of the farmers are aware about certifications and the potential benefits, only 21 percent show any willingness to adopt certifications. Cocoa certification is relatively new in Ghana (less than five years, but it has been very popular within the last two years). Although the benefits of certifications have been explained to many farmers, adopters of certification are yet to realize the full benefits. Consequently, the absence of any significant tangible benefits to scheme adopters could partly account for the lower level of willingness to adopt certifications.

Table 1. Characteristics of respondents

\begin{tabular}{lcc}
\hline Variable & Frequency(N=439) & Percent \\
\hline Gender: & 329 & 75.0 \\
$\quad$ Male & 110 & 25.0 \\
$\quad$ Female & 302 & \\
$\begin{array}{l}\text { Marital Status: } \\
\quad \text { Married }\end{array}$ & 137 & 68.8 \\
$\quad$ Single & & 31.2 \\
Membership in Farmer-based organization: & 222 & 50.6 \\
$\quad$ Yes & 217 & 49.4 \\
$\quad$ No & & \\
Membership in cocoa Farmer Association: & 88 & 20.0 \\
$\quad$ Yes & 351 & 80.0 \\
$\quad$ No & & \\
Access to credit: & 42 & 9.6 \\
$\quad$ Yes & 397 & 90.4 \\
$\quad$ No & & \\
Farmer status & 161 & 36.7 \\
Certified farmer & 278 & 63.3 \\
Conventional producer & & \\
Awareness of cocoa certification & & 52.4 \\
Yes & 230 & 47.6 \\
$\quad$ No & 209 & 21.4 \\
Willingness to adopt cocoa certification & & 78.6 \\
$\quad$ Nes & 94 &
\end{tabular}

Source: Field survey, 2013. 
The average land put under cocoa production by a typical household in the project area was estimated at 7 acres out of which 3 acres were already bearing (Table 2). The yield obtained by farmers under certification was $9.8 \mathrm{bags}(630 \mathrm{~kg})$ and that from conventional farmers was $5.8 \mathrm{bags}(370 \mathrm{~kg})$.Even though the difference in output was statistically significant at the $1 \%$ level, on per acre basis, the yield difference was not significant statistically ( 2.1 bags- $134 \mathrm{~kg}$ compared with $2.2 \mathrm{bags}-141 \mathrm{~kg}$ ). The average output of $7.4 \mathrm{bags}$ from 3.5 acres of cocoa plantation translates to a yield of about 2.14 bags $(137 \mathrm{Kg})$ per acre. This figure is a little lower than the national average of about 2.8 bags (180Kg) per acre (COCOBOD, 2006). Even though farmers are doing quite well when assessed by the national standard, there is still a long way to go when the figures are compared with average yields in Ivory Coast (320kg/acre) and Malaysia (720kg/acre). Low levels of input usage and poor farm maintenance have been cited as some of the main reasons for the yield gap between cocoa farmers in Ghana and other cocoa producing countries.

Table 2. Summary statistics describing respondents

\begin{tabular}{lrrrrrr}
\hline \multirow{2}{*}{ Variable } & \multicolumn{2}{c}{$\begin{array}{c}\text { Certified farmers } \\
\text { (Treatment) }\end{array}$} & \multicolumn{2}{c}{$\begin{array}{c}\text { Conventional farmers } \\
\text { (control) }\end{array}$} & \multicolumn{2}{c}{ Total } \\
\cline { 2 - 7 } & \multicolumn{1}{c}{ Mean } & \multicolumn{1}{c}{ Std. Dev. } & \multicolumn{1}{c}{ Mean } & Std. Dev. & Mean & Std. Dev. \\
\hline Age of Farmer & 44.4224 & 16.39783 & 41.9639 & 14.85998 & 43.0731 & 12.82355 \\
Household Size & 6.7764 & 2.21647 & 5.7834 & 2.07573 & 6.2078 & 2.71629 \\
Years of Formal Education & 4.0949 & 3.39714 & 3.2883 & 2.69448 & 3.5833 & 2.97994 \\
Farming Experience (yrs) & 19.4099 & 12.76297 & 17.1606 & 12.26683 & 17.9874 & 12.48424 \\
Number of Extension Visits & 4.8559 & 2.36928 & 1.9000 & 1.72051 & 3.1335 & 2.72004 \\
Distance to cocoa farm & 2.7603 & 2.55029 & 2.6315 & 2.03337 & 2.6907 & 2.26945 \\
Credit used last year (GHC) & 611.67 & 395.2210 & 425.30 & 394.4435 & 507.12 & 447.49 \\
Size of Land Owned (acres) & 12.4707 & 10.59567 & 10.8554 & 9.13633 & 11.4677 & 10.21667 \\
Total size of cocoa farm owned & 8.0562 & 6.02533 & 6.9940 & 5.78487 & 7.3966 & 5.89231 \\
by HH (acres) & & & & & & \\
Average age of Cocoa Farm & 14.7132 & 13.60704 & 10.3631 & 9.06548 & 12.3092 & 11.49070 \\
Size of cocoa Farm Currently & 4.7582 & 3.24034 & 2.6240 & 1.42902 & 3.4505 & 2.86005 \\
Bearing (acres) & & & & & & \\
Quantity of Cocoa Beans & 9.8462 & 12.53004 & 5.7917 & 8.36700 & 7.3889 & 10.37301 \\
harvestedlast year (bags) & & & & & & \\
\hline
\end{tabular}

It is important to highlight that certifications started very recently in the study areas (less than 2 years for some groups). Farmers are now being introduced to the various GAP and packages under the various certification labels. Significant yield differences should, therefore, be expected in the near future when practices taught have been fully employed. 
Table 3. Estimates for the logit model for willingness to adopt cocoa certification

\begin{tabular}{|c|c|c|c|c|c|}
\hline Variable & B & S.E. & Wald & Sig. & $\operatorname{Exp}(B)$ \\
\hline Sex $($ Male $=1 ; 0=$ female $)$ & 0.631 & 1.126 & 0.314 & 0.575 & 1.880 \\
\hline Access to Credit $(Y e s=1 ; N o=0)$ & $-2.046^{* *}$ & 1.021 & 4.020 & 0.045 & 0.129 \\
\hline $\begin{array}{l}\text { Awareness of certification (yes }=1 \text {; } \\
N o=0)\end{array}$ & $2.334 * * *$ & 0.878 & 7.066 & 0.008 & 10.314 \\
\hline Ln_Years of formal education & $1.775^{* *}$ & 0.785 & 5.113 & 0.024 & 5.900 \\
\hline Ln_Farmsize & -0.167 & 0.527 & 0.100 & 0.752 & 0.846 \\
\hline Ln_Extension_Visits & 0.012 & 0.562 & 0.000 & 0.983 & 1.012 \\
\hline $\operatorname{Mem} \_\mathrm{FBO}(Y e s=1 ; N o=0)$ & $2.639 * * *$ & 1.014 & 6.775 & 0.009 & 14.001 \\
\hline Ln_Farming Experience & -0.825 & 0.562 & 2.155 & 0.142 & 0.438 \\
\hline Constant & -3.260 & 2.178 & 2.242 & 0.134 & 0.038 \\
\hline
\end{tabular}

Model Diagnostics:

\begin{tabular}{ll} 
Chi-square & $42.554(\mathrm{df}=8 ; \operatorname{sig} @ 0.000)$ \\
-2 Log likelihood & 47.991 \\
Cox \& Snell R Square & 0.409 \\
Nagelkerke R Square & 0.607 \\
\hline$* * *, * *$ significant at 1\% and 5\% respectively
\end{tabular}

Membership in FBOs, awareness of certification, education level and access to credits were the main determinants of the willingness to adopt certifications, as seen in the logit model in Table 3. Quite importantly, the study found that access to credits has a significant negative effect on the willingness to adopt cocoa certifications. This is not surprising since the farmers under certifications have the purchasing power to buy chemical fertilizers and other synthetic inputs but the usage of these inputs is discouraged under these certification schemes (for example organic certifications) due to their harmful effects on the environment and human health. Farmers who have difficulties with credit accessibility will be more willing to embrace cocoa certifications, which downplay the use of these rather expensive chemical inputs in cocoa production. This finding implies that the promotion of cocoa certifications is more likely to yield positive results in terms of adoption in cocoa growing areas where access to credit is quite limited.

Membership in FBOs has a positive significant effect in the willingness to adopt certifications. This has to do with the fact that most of the certified farmers do so through the support of the associations. The awareness on certifications (meaning how much farmers know about certifications and the certification process) and the years of formal education of farmers are two factors that have a positive effect on the willingness to adopt certifications. The more knowledge and information farmers have, the more willing they are to adopt certifications. Likewise, the more formal schooling they have, the more they are willing to adopt certifications. Whereas membership in FBOs and awareness about different aspects related to certification had a significant positive effect on adoption of cocoa certification, farm size, the number of visits from extensionists and the farming experience had no significant effect on willingness to adopt certifications. 
Table 4. Constraint analysis

\begin{tabular}{|c|c|c|c|c|c|c|c|}
\hline \multirow{2}{*}{ Constraint } & \multicolumn{2}{|c|}{ Conventional } & \multicolumn{2}{|c|}{ Certified } & \multicolumn{2}{|c|}{ Total } & \multirow[b]{2}{*}{ Ranking } \\
\hline & Mean rank & Std. Dev. & Mean rank & Std. Dev. & Mean rank & Std. Dev. & \\
\hline $\begin{array}{l}\text { Limited access to or } \\
\text { unavailability of improved } \\
\text { planting material }\end{array}$ & 3.2274 & 1.91738 & 3.4286 & 1.79831 & 3.3014 & 1.87493 & 1 \\
\hline Lack of spraying machine & 3.1949 & 2.00856 & 3.2795 & 1.87153 & 3.226 & 1.95757 & 2 \\
\hline Highcost of fertilizer & 2.9747 & 1.95124 & 3.0932 & 1.83644 & 3.0183 & 1.90858 & 3 \\
\hline Inadequate storage facility & 2.8913 & 2.0367 & 2.9193 & 1.92021 & 2.9016 & 1.9924 & 4 \\
\hline Poor road infrastructure & 2.7148 & 1.90961 & 2.9193 & 1.80961 & 2.79 & 1.87399 & 5 \\
\hline Limited access to credit & 2.6354 & 1.91313 & 2.9006 & 1.8173 & 2.7329 & 1.88074 & 6 \\
\hline $\begin{array}{l}\text { Incidence of diseases and } \\
\text { pests }\end{array}$ & 2.6282 & 1.90604 & 2.8944 & 1.8221 & 2.726 & 1.87792 & 7 \\
\hline Erratic rainfall pattern & 2.619 & 1.94632 & 2.7453 & 1.75812 & 2.6659 & 1.87764 & 8 \\
\hline $\begin{array}{l}\text { Problems of government } \\
\text { fertilizer subsidies }\end{array}$ & 2.4332 & 1.84156 & 2.4907 & 1.75399 & 2.4543 & 1.80806 & 9 \\
\hline Aged cocoa trees & 2.278 & 1.86073 & 2.2174 & 1.69814 & 2.2557 & 1.80094 & 10 \\
\hline Low producer prices & 1.9745 & 1.69889 & 2.3789 & 1.62382 & 2.1239 & 1.68107 & 11 \\
\hline High cost of labor & 2.0614 & 1.63295 & 1.9938 & 1.39865 & 2.0365 & 1.54965 & 12 \\
\hline High cost of pesticides & 1.8123 & 1.52068 & 2.2484 & 1.50013 & 1.9726 & 1.52603 & 13 \\
\hline $\begin{array}{l}\text { Unavailability of land and } \\
\text { land tenure }\end{array}$ & 1.8014 & 1.7384 & 2.0373 & 1.72079 & 1.8881 & 1.73371 & 14 \\
\hline $\begin{array}{l}\text { Problems of government } \\
\text { mass spraying exercise }\end{array}$ & 1.3696 & 1.33798 & 1.5093 & 1.34219 & 1.4211 & 1.3397 & 15 \\
\hline $\begin{array}{l}\text { Cheating by purchasing } \\
\text { clerks }(\mathrm{PC})\end{array}$ & 1.2836 & 1.18672 & 1.4534 & 1.25474 & 1.3463 & 1.21362 & 16 \\
\hline $\begin{array}{l}\text { Delays in repayment for } \\
\text { cocoa purchased }\end{array}$ & 1.1311 & 0.74107 & 1.1724 & 0.56624 & 1.1513 & 0.65921 & 17 \\
\hline
\end{tabular}

Scale: $1=$ unimportant, $2=$ slightly important; $3=$ Important; $4=$ very important; $5=$ critically important

A constraint analysis was conducted in order to determine which factors are affecting cocoa farmers in the Ashanti region in Ghana (Table 4). The farmers clearly indicated that the main problem they are currently facing is the limited access to improved hybrid material for planting or renewing their plantations. The average farm age among the interviewed farmers was 12.3 years. Much of the material in their plantations is not as high-yielding as the new improved hybrid material, which 12 to 15 years ago was not available to them. Because of the lower yields, farm inputs such as fertilizers are widely used in this region and for farmers, the price is quite high. This is also one of the main constrains they face in cocoa production. They also lack appropriate farm equipment for spraying pesticides (mostly conventional farmers) and the incidence of pest and diseases was mentioned as another main constraint. In addition, farmers mentioned that the subsidies for fertilizers provided by the government are sometimes not reaching them. There is general subsidy on fertilizer for all farmers and all crops in Ghana. However, there are continuous shortages in the system created to take advantage of farmers. This can lead to artificial price increases, which dramatically affect small-scale farmers. The resources cocoa farmers have are quite limited. Even at the current subsidized price of about GHC50 per $50 \mathrm{~kg}$ bag, NPK is considered to be very expensive by farmers. Farmers also consider the prices of other farm inputs such as pesticides to be very high.

Furthermore, the infrastructure is not optimal and the access to the collection points is also difficult. The road 
conditions are poor and getting the beans to the collection centers is often a task that must be conducted by the farmers themselves. The poor storage facilities, which farmers mention as a main constrain, have a direct impact on the quality of the beans. The fermentation of the beans is done on the farm, where the beans are placed in heaps on the ground and covered by banana leaves. Few farmers do the fermentation in wooden boxes. The drying of the beans is done in raised beds so the humidity is well-controlled for, but farmers may also face the risk of losses due to inadequate storage facilities in their homes. Those farmers in remote areas have an even higher risk of loss due to inadequate facilities, mainly because purchasing clerks visit them and buy the beans only periodically. Payment problems are not uncommon, according to the farmers. There are still reports of purchasing clerks cheating farmers and delays in the payments made to the farmers, despite efforts from the side of COCOBOD to correct this problem. In general, farmers still find that the price paid for their cocoa beans is low.

Finally, environmental problems are also affecting farmers and they mentioned that the irregular rainfall patterns they are now seeing and the increased incidence of pests and diseases are additional constraints. The irregular rainfalls can potentially be a critical factor, mostly because of the inadequate storage facilities farmers have. Humidity can dramatically affect the bean quality, and great losses can be incurred by farmers if they are not able to control these environmental factors.

\section{Discussion}

Even though cocoa farmers in the Ashanti region of Ghana are well-aware about the benefits of certifications and sustainable production methods, the adoption rate is still under 40 per cent. Over 75 per cent of the farmers were unwilling to adopt certifications. Despite the fact that empirical evidence point towards benefits for the farmers, in this case it is not yet evident. The certification process is usually accompanied by better prices paid to the producer (Doherty and Meehan, 2006), but more importantly by training and aid in the whole certification process. The benefits associated with improved yield as a result of training and sustainable production methods take time to manifest. Since cocoa certification is relatively new in Ghana, farmers are yet to realize significant yield benefits for certification to attract cocoa farmers who are not currently under certification. The results of this study have shown that the willingness to adopt cocoa certification by farmers in the Ashanti Region of Ghana is significantly influenced by access to credits, awareness of certifications, the educational level of farmers and FBO membership. Awareness creation about certifications through periodic education/sensitization, especially in cocoa growing communities that have limited access to credit, will significantly improve the adoption of certification and sustainable production methods in the Ghanaian cocoa industry. Sustainable production methods will reduce depletion of forest lands, minimize the excessive use of inorganic farm inputs and protect flora and fauna to ensure balanced ecosystem and biodiversity conservation. Sensitization and education on the benefits of sustainable cocoa production methods should be intensified among farmers. Also, the needed training and capacity building should be undertaken by Cocobod and other stakeholders in the cocoa value chain to ensure that farmers shift from unsustainable farming practices to more sustainable methods to enhance cocoa productivity in Ghana whilst ensuring environmental stewardship.

\section{Acknowledgement}

The authors express their gratitude to the Rector's Conference of the Swiss Universities of Applied Sciences for the financial support for the execution and completion of this research project.

\section{References}

Abekoe, M. K., Obeng, O. I., \& Egyir, I. S. (2002). Technology of Cocoa in the Forest Zone of Ghana, Report presented at the Convergence of Sciences' International Workshop, 23-29 March, 2000, Benin.

Amos, T. T. (2007). An Analysis of Productivity and Technical Efficiency of Smallholder Cocoa Farmers in Nigeria. J. Soc. Sci., 15(2), 127-133.

Appiah, M. R. (2004). Impact of Cocoa Research Innovations on Poverty Alleviation in Ghana. Ghana Academy of Arts and Sciences, Liberatin Link, Accra, Ghana.

Appiah, M. R. (2005). Adopt Research to Improve Cocoa Production. Cocoa Research Institute, Printing Division, Tafo, Ghana.

Appiah, M. R., Ofori-Frimpong, K., \& Afrifa, A. A. (2000). Evaluation of Fertilizer Application on Some Peasant Cocoa Farms in Ghana. Ghana Journal of Agricultural Sciences, 33, 183-190.

Asamoah, M., \& Baah, F. (2003).Improving Research-Farmer linkages: The role of Cocoa Research Institute of Ghana (CRIG). A paper submitted at the $4^{\text {th }}$ international seminar on cocoa Pests and Diseases (NECOPED) 
Accra, Ghana. $19^{\text {th }}-21^{\text {st }}$ October, 2003.

Bank of Ghana. (2007). Balance of payments, Bank of Ghana Annual report, Accra, Ghana.

Binam, J. N., Gockowski, J., \& Nkamleu, G. B. (2008).Technical Efficiency and ProductivityPotential of Cocoa Farmers in West African Countries. The Developing Economies, XLVI(3), 242-263. http://dx.doi.org/10.1111/j.1746-1049.2008.00065.x

Bulir, A. (1998). The price incentive to smuggle and the cocoa supply in Ghana, 1950-96.

Chamberlin, J. (2008). It's a small world after all: Defining smallholder agriculture in Ghana. IFPRI Discussion Paper, 00823.

Clemens, B., Diao, X. S., Kolavalli, S., \& Thurlow, J. (2008).The role of cocoa in Ghana's future development; Ghana Strategy Support Program (GSSP), IFPRI Background Paper, No. GSSP 11.

COCOBOD. (2007). Cocoa Production and Price statistics, Ghana COCOBOD, Accra, Ghana.

Doherty, B., \& Meehan, J. (2006).Competing on social resources: The case of the Day Chocolate Company in the UK confectionery sector. Journal of Strategic Marketing, 14(4), 299-313. http://dx.doi.org/10.1080/09652540600947847

Doherty, B., \& Tranchell, S. (2005). New thinking in international trade? A case study of The Day Chocolate Company. Sustainable Development, 13, 166-176. http://dx.doi.org/10.1002/sd.273

Dormon, E., van Huis, A., Leeuwis, C., Obeng-Ofori, D., \& Sakyi-Dawson, O. (2004). Causes of low productivity of cocoa in Ghana: farmers' perspectives and insights from research and the socio-political establishment. NJAS Wageningen. Journals of Life Science, 52(3/4), 237-259. http://dx.doi.org/10.1016/S1573-5214(04)80016-2

FAO. (2013). Analysis of incentives and disincentives for cocoa in Ghana. Technical notes series, MAFAP, FAO, Rome.

GAIN. (2012). Annual cocoa report for Ghana, Product Brief by United States Department for Agriculture (USDA) Foreign Agricultural Service, GAIN Report Number GH1202, Published by Global Agricultural Information Network (GAIN). Retrieved from http://gain.fas.usda.gov/Recent\%20GAIN\%20Publications/Cocoa\%20Report\%20Annual_Accra_Ghana_315-2012.pdf

Gockowski, J., Afari-Sefa, V., Sarpong, D., Osei-Asare, Y., \& Dziwornu, A. (2011). Increasing income of Ghanaian cocoa farmers: Is introduction of fine flavor cocoa viable alternative? Quarterly Journal of International Agriculture, 2(50), 175-200.

GSS. (2012). Provisional Gross Domestic Product 2012, National Accounts Statistics, Published by Ghana Statistical Service (GSS) in September 2012, Accra, Ghana.

ICCO. (2007). Annual report for 2005/2006 cropping season, International Cocoa Organisation, London.

ISSER. (2011). The State of the Ghanaian Economy in 2010.Institute of Statistical, Social and Economic Research, University of Ghana, Legon, 2011.

McKay, A., \& Aryteey, E. (2005).A country case study on Ghana. Operationalising Pro-Poor Growth work program: A joint initiative of the French Development Agency (AFD), Federal Ministry for Economic Cooperation and Development (BMZ): German Agency for Technical Cooperation (GTZ) and KfW Development Bank, U.K. Department for International Development (DFID), and the World Bank.

MOFA. (2006). Agriculture in Ghana in 2005, Annual Report of the Ministry of Food and Agriculture, Accra, Ghana.

MOFA. (2007). Agriculture in Ghana in 2006, Annual Report of the Ministry of Food and Agriculture, Accra, Ghana.

Mohammed, D., Asamoah, D., \& Asiedu-Appiah, F. (2011). Cocoa Value Chain -Implication for the Smallholder Farmer in Ghana. Department of Information Systems and Decision Sciences, KNUST School of Business, Kwame Nkrumah University of Science \& Technology, Ghana.

Nkamleu, G. B., Nyemeck, J., \& Gockowski, J. (2010). Technology Gap and Efficiency in Cocoa Production in West and Central Africa: Implications for Cocoa Sector Development, Working Papers Series No. 104, African Development Bank, Tunis, Tunisia. 
Toenniessen, G., Adesina, A., \& DeVries, J. (2008). Building an Alliance for a Green Revolution in Africa. Annals of the New York Academy of Sciences, 1136(1), 233-242. http://dx.doi.org/10.1196/annals.1425.028

UNDP. (2012). Environmental Sustainability and Policy for Cocoa Production in Ghana; Ghana Cocobod and UNDP project document.

\section{Appendix A}

ANOVA Conventional vs. Certified Cocoa Producers

\begin{tabular}{|c|c|c|c|c|c|c|}
\hline \multicolumn{2}{|c|}{$\begin{array}{l}\text { Variable paired with farmer status } \\
\text { (conventional vrs certified cocoa producer) }\end{array}$} & \multirow{2}{*}{\begin{tabular}{|l|}
$\begin{array}{c}\text { Sum of } \\
\text { Squares }\end{array}$ \\
7284.744
\end{tabular}} & \multirow{2}{*}{$\begin{array}{r}\text { df } \\
1\end{array}$} & \multirow{2}{*}{$\begin{array}{r}\text { Mean Square } \\
7284.744\end{array}$} & \multirow{2}{*}{$\begin{array}{c}\mathbf{F} \\
14.414\end{array}$} & \multirow{2}{*}{$\begin{array}{l}\text { Sig. } \\
.000\end{array}$} \\
\hline Age of Farmer * & * Between Groups & & & & & \\
\hline \multirow[t]{2}{*}{ Farmer Status } & Within Groups & 220354.918 & 436 & 505.401 & & \\
\hline & Total & 227639.662 & 437 & & & \\
\hline Household Size * & * Between Groups & 4999.140 & 1 & 4999.140 & 9.052 & .003 \\
\hline \multirow[t]{2}{*}{ Farmer Status } & Within Groups & 240796.954 & 436 & 552.287 & & \\
\hline & Total & 245796.094 & 437 & & & \\
\hline Years of Formal & 1 Between Groups & 65.201 & 1 & 65.201 & 4.146 & .042 \\
\hline Education $*$ Farmer & r Within Groups & 6761.799 & 430 & 15.725 & & \\
\hline Status & Total & 6827.000 & 431 & & & \\
\hline Farming experience * & * Between Groups & 515.136 & 1 & 515.136 & 3.323 & .069 \\
\hline \multirow[t]{2}{*}{ Farmer Status } & Within Groups & 67594.045 & 436 & 155.032 & & \\
\hline & Total & 68109.181 & 437 & & & \\
\hline Number of Extension & Between Groups & 565.119 & 1 & 565.119 & 18.406 & .000 \\
\hline \multirow[t]{2}{*}{ Visits * Farmer Status } & Within Groups & 8105.394 & 264 & 30.702 & & \\
\hline & Total & 8670.512 & 265 & & & \\
\hline Distance to cocoa farm & Between Groups & .565 & 1 & .565 & .052 & .819 \\
\hline \multirow{2}{*}{ * Farmer Status } & Within Groups & 1453.176 & 135 & 10.764 & & \\
\hline & Total & 1453.741 & 136 & & & \\
\hline Amount of Credit * & * Between Groups & 350697.521 & 1 & 350697.521 & 1.175 & .285 \\
\hline \multirow[t]{2}{*}{ Farmer Status } & Within Groups & $1.164 \mathrm{E} 7$ & 39 & 298449.612 & & \\
\hline & Total & $1.199 \mathrm{E} 7$ & 40 & & & \\
\hline \multirow{3}{*}{$\begin{array}{l}\text { Size of Land Owned * } \\
\text { Farmer Status }\end{array}$} & * Between Groups & 246.247 & 1 & 246.247 & 1.525 & .218 \\
\hline & Within Groups & 64439.236 & 399 & 161.502 & & \\
\hline & Total & 64685.483 & 400 & & & \\
\hline \multirow{2}{*}{$\begin{array}{l}\text { Total Cocoa farm } \\
\text { owned by Household * }\end{array}$} & Between Groups & 106.492 & 1 & 106.492 & 3.083 & .080 \\
\hline & * Within Groups & 13781.233 & 399 & 34.539 & & \\
\hline Farmer Status & Total & 13887.725 & 400 & & & \\
\hline Average Age of Cocoa & a Between Groups & 711.133 & 1 & 711.133 & 5.548 & .020 \\
\hline \multirow[t]{2}{*}{ Farm * Farmer Status } & Within Groups & 19226.334 & 150 & 128.176 & & \\
\hline & Total & 19937.467 & 151 & & & \\
\hline \multirow{4}{*}{$\begin{array}{l}\text { Size of cocoa Farm } \\
\text { currently Bearing * } \\
\text { Farmer Status } \\
\text { Cocoa Beans harvested }\end{array}$} & Between Groups & 220.490 & 1 & 220.490 & 9.737 & .002 \\
\hline & * Within Groups & 4574.380 & 202 & 22.645 & & \\
\hline & Total & 4794.870 & 203 & & & \\
\hline & Between Groups & 777.110 & 1 & 777.110 & 7.459 & .007 \\
\hline
\end{tabular}




\begin{tabular}{|c|c|}
\hline last year & 104.183 \\
\hline Status & \\
\hline
\end{tabular}

\section{Copyrights}

Copyright for this article is retained by the author(s), with first publication rights granted to the journal.

This is an open-access article distributed under the terms and conditions of the Creative Commons Attribution license (http://creativecommons.org/licenses/by/3.0/). 